\title{
Teaching Foresight and Futures Literacy and Its Integration into University Curriculum
}

\author{
Anna Kononiuk \\ Assistant Professor, a.kononiuk@pb.edu.pl \\ Bialystok University of Technology 45 AWiejska Street, 15-351 Bialystok, Poland \\ Anna Sacio-Szymańska \\ Researcher ${ }^{\mathrm{a}}$ and beFORE Project Coordinator ${ }^{\mathrm{b}}$, anna@4cf.pl \\ ${ }^{a}$ 4CF Strategic Foresight, Plac Trzech Krzyzy 10/14, 00-499 Warszawa, Poland \\ ${ }^{\mathrm{b}}$ Lukasiewicz Research Network — Institute for Sustainable Technologies, K. Pulaskiego 6/10, 26-600 Radom, Poland \\ Stefanie Ollenburg \\ Researcher, s.ollenburg@fu-berlin.de \\ Freie Universitaet Berlin, Fabeckstr. 37, 14195 Berlin, Germany \\ Leonello Trivelli \\ Researcher, leo.trivelli@gmail.com \\ University of Pisa, Department of Civil and Industrial Engineering, Largo L. Lazzarino 56122, Pisa, Italy
}

\begin{abstract}
$\mathrm{D}$ espite the accelerated dynamics of the environment, higher education institutions slowly update their curricula in entrepreneurship education according to global challenges and market needs. Moreover, knowledge and good practice exchange between educators of futures studies, business representatives and academics is limited. This article aims to present the methodology of prototyping an online course for individuals to become more future-oriented in their professional and personal settings. The main research problems tackled by the authors relate to: 1) identification of competences that would help academics, entrepreneurs and students to deal with uncertainty and to 2) convey the competences to the target groups through learning topics selected from futures

studies and the entrepreneurship repertoire. The authors of the article undertook and coordinated theoretical and empirical research on foresight and futures literacy and its correspondence with entrepreneurship within the beFORE project funded under the Erasmus+ programme Knowledge Alliance scheme. The research process resulted in identification of 12 key competence items and development of the free approximately 34 hours long online course consisting of seven self-standing modules, 25 lessons and 79 learning topics corresponding to these competences. The originality of the paper is in its contribution to the discussion on the competences and online course contents that efficiently increase the capacities of using the future(s) in professional, academic and personal settings.
\end{abstract}

Keywords: foresight; long-term strategies; future-orientation; Futures Literacy; entrepreneurship; competences; eLearning

Citation: Kononiuk A., Sacio-Szymańska A., Ollenburg S., Trivelli L. (2021) Teaching Foresight and Futures Literacy and Its Integration into University Curriculum. Foresight and STI Governance, 15(3), 105-121. DOI: 10.17323/25002597.2021.3.105.121 


\section{Introduction}

For a long time, entrepreneurs were thought to be "bearers of uncertainty" [Knight, 1921], disruptors of market equilibria [Schumpeter, 1934] or the source of changes that result in the establishment of equilibria [Walras, 1954]. Indeed, the ability to envision new contexts in which products and services would be able to delineate different ways of life and new forms of society and wealth has always been one of the most characterizing traits of entrepreneurs.

After 2009, the European Commission underlined the importance of entrepreneurship in its Entrepreneurship Action Plan which stated that having a higher number of entrepreneurs would help Europe return to a growth trajectory [European Commission, 2012]. At the same time, a growing number of initiatives aimed at supporting the creation of new companies started all over the world [Bridge, 2017] and entrepreneurship education programs considerably increased in the last few years [Jones et al., 2018]. According to [Thomassen et al., 2018], entrepreneurship education has been widely investigated in recent decades with the goal of framing which aspects might be taught and which skills are the more important to train new entrepreneurs.

Entrepreneurial skills and competences taught to students during their time at university are limited to financial [Ratcliffe, Ratcliffe, 2015], economic literacy [Fontela, 2006], and human resources management [Hurst, 2014].

Meanwhile, future and acting entrepreneurs need open access to knowledge about models, methods, and tools, which should enable them to build and constantly reinvent so-called future-proof strategies. These are the strategies, which take into account potential future challenges and opportunities, which question assumptions about the future to find the loadbearing solutions. These are the ones upon which the plan rests in order to seek solutions that are implementable in the context of various alternative scenarios and the organizational external environment. Developing such strategies requires competences of futures thinking and/or futures literacy. ${ }^{1}$

In this paper we argue that futures thinking is the competence that should complement curricula taught at faculties of entrepreneurship and we present a methodology for prototyping an online course in futures thinking with the ambitious goal of producing futures literate individuals and entrepreneurs. ${ }^{2}$

In our competence-based methodological approach, we blend the theory of futures studies and the practice of strategic foresight, in a part that refers to individual or organizational futures thinking ability [Hines et al., 2017; Dannenberg, Grapentin, 2016; Ratcliffe, Ratcliffe, 2015; van der Laan, Erwee, 2012; Rohrbeck, 2011].

In this article, we refer to futures thinking as synonymous with futures literacy. We perceive both futures literacy and futures thinking as competences to cope with the future. Futures studies offer a range of tools to support futures thinking and the identification and interaction of trends, such as trend analyses, scenario methods, which help to structure thinking about the future and thus make futures thinking and futures literacy learned competences. We argue that those competences should become skills for the 21st century just like digital literacy, internet literacy, or information literacy [Stordy, 2015]. Similarly to futures thinking, we treat the term literacy as the capability not only to imagine the future or futures but also to create it in more diverse ways for different purposes, which can be seen as a competence that allows entrepreneurs to address $21^{\text {st }}$ century challenges [Miller, 2018]. Therefore, our ambition is to make it a learned skill by offering a free, approximately 34-hour-long online course on foresight and futures literacy.

\section{Research Objective and Questions}

The capability of futures thinking and/or futures literacy as well as related competences can be further developed through exposure to the discourse on futures concepts, methods for studying the future, and its applications [Alsan, 2008; Miller, 2018].

Building on previous research [Nanus 1997; Alsan 2008; Miller 2018] we hypothesize that introducing the theory of futures studies and the practice of strategic foresight into entrepreneurial education and business culture can enhance futures thinking capabilities and increase resilience skills.

However, despite the relevant contribution that futures literacy can bring to entrepreneurship education, the openness of universities to transforming traditional entrepreneurship curricula is limited [Clark, 2003].

Therefore, this research aims to present a methodological approach for the design and implementation of an open access educational course in future-orientated entrepreneurship, delivered through e-learning platforms. As an example, the authors introduce the Erasmus + Knowledge Alliance project entitled: "Becoming future-oriented entrepreneurs in universities and companies - beFORE"3, its methodology, and the resulting prototype e-learning offer aimed at equipping individuals with futures thinking competences.

The objective of this paper is to further the discussion on the competences and online course content that efficiently increase the capacities of using the future in professional, academic, and personal settings.

Therefore, the research questions that the authors address in the paper are:

- Which competences do individuals need to be more future-oriented and in the long term to become futures literate in professional and educational environments?

- Which educational topics would best help in developing such competences through one coherent online educational course?

As part of the consortium, the authors reflect upon the beFORE project process to design online training programs (as shown in Figure 1) in order to offer a critical view on ways to identify future-oriented competences through the lens of

\footnotetext{
${ }^{1}$ Futures Literacy is a cognitive competence, which allows one to: creatively envision possible futures, discover assumptions about the future, reframe and enrich future visions, expand the boundaries of perception of the present and make sense of the present, sense and describe change, stimulate initiative and agency - accordingly with or against changes/shocks, and enhance reflexivity [Miller, 2018].

2 The definition of "entrepreneur" that we apply in this paper is: a "person having the ability to accurately assess situations, people, facts and events and turn this to one's advantage." (Online Oxford dictionary 2017). https://english.stackexchange.com/questions/79572/single-word-for-taking-advantage-of-thesituation, accessed 14.05.2021.

${ }^{3}$ www.futureoriented.eu, accessed 14.05.2021.
} 
what has been taught (the supply side) and what is most valued by target groups (the demand side).

\section{Identifying Future-Oriented Competences and Learning Needs}

\section{Reviewing and synthetizing studies, university curricula, courses and case studies to extract futures literacy, foresight and entrepreneurial competences}

As demonstrated in the 2006 European Reference Framework for Key Competences for Lifelong Learning, in a world of high dynamism, unpredictable changes, and volatility [Kaivooja, Laureus, 2018], futures literate individuals will have a better chance of securing new employment [Gudanowska et al. 2020]. Future-oriented thinking is a core competence because it is the foundation for imagination, strategy development, and the creation of a preferred future for individuals and at organizations [Inayatullah, 2008]. Foresight competences make a contribution to the successful realization of the strategy in higher education mergers [Sajwani et al., 2021]. In addition to problem-oriented learning, foresight competences that allow for goal-building and developing students' readiness to undertake change should be introduced into educational processes [ETF, 2017]. A similar view related to career guidance training can be found in [Kononiuk et al., 2020]. Foresight competence belongs to the dynamic capabilities of the educational enterprises [Arpentieva et al., 2020]. The authors emphasize that these competences allow for the transformation of organizational routines thus allowing not only for predicting the "unpredictable", but also for a more favorable configuration of organizational resources.

Therefore, the first step of the presented research is the identification of future-oriented competences which could be relevant to integrate into entrepreneurship education programs. The authors of this article understand competences as the knowledge and skills that are indispensable for carrying out specific tasks in an effective way [Volpentesta, Felicetti, 2011; Gudanowska et al., 2020]. In line with [Suleiman, Abahre, 2020], the authors of the article perceive competences as personal dispositional capabilities used to act successfully in new situations.

The literature review implies that a multitude of competences are considered essential or at least useful for future-oriented entrepreneurs. The examples of future-oriented entrepreneur competences retrieved from the publications are presented in Table 1.

Entrepreneurial competences that are often mentioned in the existing publications are: lack of risk-aversion [Jain, 2011], high risk management skills [Morris et al., 2013], creativity [Bell, 2009; Rohrbeck, 2011], innovativeness, internal locus of control [Jain, 2011], networking skills, and the ability to identify opportunities [Rohrbeck, 2011] and learn from mistakes [Lewrick et al, 2010] .

On the other hand, foresight competences should liberate the mind from its old assumptions and sensitize it to the earliest signals of change [Weiner, Brown, 2008]. Therefore, among the foresight competences mentioned by these authors are: the acceptance of signals of change, challenging assumptions, looking at a problem from many perspectives, propensity to identify countertrends, understanding complexity, the ability to see the whole context, understanding evolutionary changes, questioning consensus, and understanding the dangers of efficiency which may threaten a less appreciated source of competitive advantage: resilience [Martin, 2019]. Foresight competences are not the same as entrepreneurial competences per se but may be considered supportive.

The literature review demonstrated that authors focused on different competences, mainly due to the school of thought (of foresight/futures studies) they adhere to as well as how they "use" the future as a concept. Therefore, the competences mentioned focus either more on analytical skills [Bell, 1997], creativity [Chiu, 2012], reflective and social skills [Inayatullah, 2008; Ratcliffe, Ratcliffe, 2015], interdisciplinary anticipation in thinking and acting [Dannenberg, Grapertin, 2016], or exploring the potential of the present to give rise to the future [Miller, 2018].

The literature review focused on the competences of individuals, rather than on organizational capabilities. However, the state-of-the-art analysis also included selected works [Rohrbeck, 2011; Grim, 2009; Fuller et al., 2008;], which provided the authors of the article with a broader context of entrepreneurship and foresight research, resulting in specifying critical organizational future-orientation capabilities. These relate to information usage, method sophistication, people and networks, organization, culture [Rohrbeck, 2011]; leadership, framing, scanning, forecasting, visioning, planning [Grim, 2009]; experimenting, reflexivity, organizing, and sensitivity [Fuller et al., 2008]

The literature review has been complemented by an analysis of the best corporate foresight cases and best educational practices following the criteria of indicating best practices $[\mathrm{Xu}$, Yeah, 2012] such as: universality of practice, repeatability, its methodological character, and novelty.

In the same way as in the case of the literature review, good business practices were analyzed. The data for the analysis were obtained on the basis of direct contacts with companies, information on company websites, or scientific publications that deal with the issues of competences of a future-oriented entrepreneur [Hiltunen, 2013; Rudzinski, Uerz, 2014; Andriopoulos, Gosti, 2006; Cuhls, Johnston, 2008; Wippel 2014; van der Heijden, 2000; van Atta et al. 2011; Rohrbeck 2011; Song, Hormuth 2013; Keller, 2013].

Moreover, the project consortium also investigated 17 foresight courses [Ejdys et al., 2019] conducted worldwide. Existing best educational practices were identified on the basis of the criteria mentioned above and a detailed analysis of the database of higher education offers regarding the convergence among futures studies, entrepreneurship, and innovation. All in all, out of 193 investigated sources, 1,242 items were identified.

\section{Harmonizing futures literacy, foresight, and entrepreneurship competences}

The second phase of the process had the goal of harmonizing the 1,242 items identified in the literature review phase.

To pursue such a goal, two concurrent approaches were adopted. The first (top down) was based on a qualitative analysis of the competences performed by the foresight experts. The second (bottom-up) was to analyze the results of the literature review with text mining approaches [Fareri et al., 2020; Lefebvre et al., 2013] in order to widely evaluate all appearing phrases and to extract emerging competences from the 1,242 items previously identified. In this way, the authors of the study 


\section{Figure 1. Online Training Program Design Process}

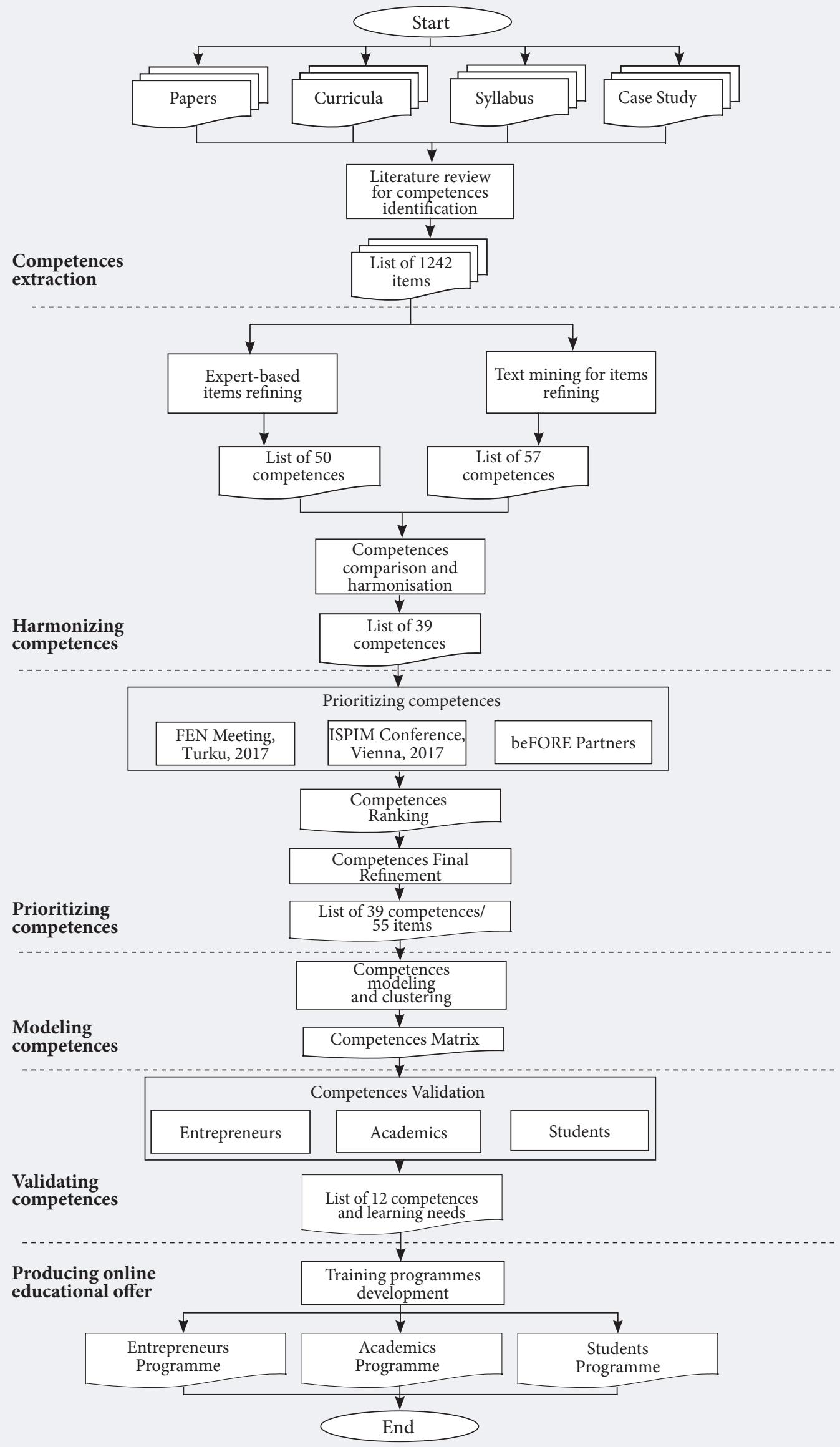

Source: authors. 
sought to ensure the triangulation of research methods. This concept in the social sciences should be treated metaphorically - as the evaluation of the phenomenon under study from different points of view in order to better understand its multifaceted nature [Denzin, 1978; Jonsen, Jehn, 2009] and to improve the reliability of the research process [Begley, 1996].

The results of this activity was a pilot list of 39 competences (Box 1).

The list is the result of the literature review, the application of data mining techniques, and the discussions about future-oriented competences of the target groups (students, academics, and business people) held by the project partners.

\section{Prioritizing, modeling, and clustering futures literacy, foresight and entrepreneurship competences}

The pilot list of 39 competences was then further evaluated independently by 39 foresight experts and separated into three groups:

- the first group was selected from among the participants of the $\mathrm{FEN}^{4}$ meeting and the conference Futures of a Complex World (June 13-14, 2017 - Turku, Finland);

- the second group was identified during the XXVIII ISPIM $^{5}$ conference (June 18-21, 2017 - Vienna, Austria);

- the third group were selected by the beFORE project partners' representatives from academia and business.

These evaluations were performed through dedicated questionnaires which aimed to identify the most important foresight competences for entrepreneurs, students, and academics. The results of such investigations provided an initial ranking of the 39 competences.

The final step of the competence identification process was the setup of a map which outlined the competences to be acquired by entrepreneurs, academics, and students to develop a future-oriented mindset. In this phase, the competences were re-grouped and put into a conclusive correlation considering the three target groups (i.e., entrepreneurs, academics, and students) as well as their relationship to time (i.e., future orientation). Therefore, to establish a matrix for mapping the competences, a focus was placed on their competence fields, the relevant target groups, and the timeframe of short-, medium-, and long-term future-orientatio [Bell,1997; Kreibich et al., 2011; Gidley, 2016].

The following matrix was established where four quadrants define four main competence fields based on EU specifications ${ }^{6}$ :

- Knowledge - "Cognitive competence (C) involving the use of theory and concepts, as well as informal tacit knowledge gained experientially..."

- Technical abilities (skills) - "Functional competence (F) (skills or know-how), those things that a person should be able to do when they are functioning in a given area of work, learning, or social activity ..."

- Social skills - "Personal competence (P) involving knowing how to conduct oneself in a specific situation ..."

- Self-assessment (reflexive) abilities - "Ethical competence
(E) involving the possession of certain personal and professional values ..."

The $\mathrm{X}$-axis plots the items' relevance on a timeframe of the future. The division considers how a competence relates to future-awareness, decision-making, present/future actions on a personal level, for an organization, the ecosystem, and even globally. The timeframes are:

- short-term - under five years) (S)

- medium-term - five to 20 years $(\mathrm{M})$

- long-term - 20+ years(L)

The Y-axis plots the items according to the general learning objectives differentiating the target groups:

- Students: to receive knowledge / to understand (U)

- Entrepreneurs: to be able to apply (A) knowledge

- Educators: to learn how to educate/teach (T) said knowledge

The matrix (Figure 2) was the foundation for a mapping workshop to group the competences along the axis in a team effort.

The procedure revealed that there are competences, which may be significant for general education in entrepreneurship or relevant only in the short term but have less effect on the medium/long term or the ability to engage in futures thinking. These phrases were marked in grey to be excluded for further evaluation. The resulting list maps the items along the competence field, the general learning objective, and time (future) frame (Table 2).

Starting from the updated list created thanks to the mapping activity, the project consortium worked to match those complex sentences with the competences identified in the $\mathrm{O}^{*} \mathrm{NET}$ database (Table 3).

It provided important insights for defining and grouping the competences. In this activity, a list of elements was selected to decompose the 39 competences in items that were specific enough to be considered basic skills and to be taken into consideration according to a common level of granularity.

With this explorative process the project partners were able to define twelve competences (Figure 3 ).

This reduction of complexity was necessary to get an overview. Although those general competences are not unique for foresight or futures literacy, they overlap with the list of 39 competences.

The relationships developed in the group work by the authors of the article between the 39 competences and the twelve general competences are shown in Table 4. For instance, to be able to define, identify, and analyze trends within the micro- and macroenvironment of a company, one must have the ability to analyze data and information, demonstrate critical thinking and inductive reasoning, and know how to interpret the meaning of information conveyed by trends. Analyzing Table 4 , it can also be noted that there are specific competences which are very broad in meaning and require the involvement of all twelve general competences. These include: the ability to manage projects, the ability to develop organizational resilience, the ability to run strategic foresight within an organiza-

\footnotetext{
${ }^{4}$ FEN is the Foresight Europe Network http://www.feneu.org/, accessed 18.04.2021.

${ }^{5}$ ISPIM is the the International Society for Professional Innovation Management. www.ispim-innovation.com, accessed 22.05.2021.

${ }^{6}$ http://www.eucen.eu/EQFpro/GeneralDocs/FilesFeb09/GLOSSARY.pdf, accessed 09.03.2020.
} 


\section{Table 1. Future-Oriented Entrepreneur Competences Retrieved from the Publications}

Authors

[Inayatullah, 2008]

\begin{tabular}{l} 
\\
\hline [Weiner, Brown, \\
2008]
\end{tabular}

\begin{tabular}{|l|}
\hline [Bell, 2009] \\
\hline [Lewrick et al., \\
2010]
\end{tabular}

[Jain, 2011]

capacity to reflect, i.e. developing an understanding of one's past present and expectations fo ( implicit asurestly implicit assumptions on epistemological foundations of reality, e.g., discourses and myths (deepening the future);
ability to formulate preferences or make conscious choices on a normative basis ("transforming the future"); logical thinking and ability to deduce from historical experiences ("anticipation")

[Rohrbeck, 2011] abilite goals, gather information, and learn), internal locus of control, healthy self-esteem, high level of self-efficacy acceptance of signals of change, challenging assumptions, looking at a problem from many perspectives, propensity to identify countertrends, understanding complexity, ability to see a whole context, understanding evolutionary changes, questioning consensus, understanding the dangers of efficiency

prospective thinking, i.e., the ability to imagine and explore alternative futures; creativity; lateral thinking, i.e., the ability to imagine futures also going beyond the obvious development; visionary combined with factual thinking linking images of the future to present day behavior and their consequences

[Rohrbeck, 2011] ability to capture external data, ability to effectively disseminate information and insights into the organization, ability to look outside company boundaries and continuous scanning of the periphery, ability to translate strategy into action, ability to communicate clearly and concisely, ability to use creativity to identify opportunities and take risks, ability to connect and inspire other people to invest their efforts in new topics, ability to create an environment of trust

[Chiu, 2012]

[Heinonen, Ruotsalainen, 2012]

[van der Laan,

Erwee, 2012] behavioral flexibility; constructing mental representations of possible futures; creative thinking

leadership qualities: making of decisions with new business models in mind, comprehension of the importance of developing measurement systems to control innovation initiatives and strategic direction

ability to discover opportunities, lack of risk-aversion (moderate or high risk-taking propensity — inconclusive

interaction competence, collaboration competence, time competence, technology competence, environmental competence, systems competence, socio-cultural sense-making competence interrogating the future; future-time orientation, interest in the long-term issues that define the future, envisioning
"bigger picture" futures, adjusting to new situations as the future demands, balancing multiples challenges and choices, helping others to adapt, flexible leadership, influencing change, adopting new trends, confirming the diffusion of innovation theory, experimenting with new trends when they arise, opportunistic trend analysis, preserving one's own position, mitigating and resisting change

[Morris et al., $\quad$ opportunity recognition, opportunity assessment, risk management/ mitigation, conveying a compelling vision, 2013] tenacity/ perseverance, creative problem solving/ imaginativeness, resource leveraging, guerrilla skills, value creation, maintain focus yet adapt, resilience, self-efficacy, building and using networks

[Ratcliffe, Ratcliffe, awareness of self, situation, and environment, authenticity - values, truth, direction, good spirit, communication, 2015] cultivating culture /relationships, audacity challenge, inspire, enable, model, encourage; adaptability - purpose and choices, looking at system from a distance, embracing differences, action - bringing together, managing the "clever" iterative process

[Dannenberg, Grapentin, 2016]

[Gheorghiua et al., 2016] integration of new perspectives and a global view in knowledge generation; interdisciplinary anticipation in thinking and acting; identification and assessing risks and uncertainties, acting and planning in cooperation, participation in thinking and acting; identification and assessing risks and uncertainties, showing empathy and solidarity

[Miller, 2018] ensuring ecosystemic transparency, mapping emerging global trends, among others though horizon scanning mechanisms such as technological radars for weak signals; entrepreneurial dialogue through consensus-seeking consultation instruments involving broad participation

[Miller, 2018]

Futures Literacy is understood as an individual's capacity to explore the potential of the present to give rise to the future. Sense-making, seen as the ability to discover, invent, and construct the world around us. Capacity of "sensing the change" and "making sense" of change and of the reality that emerges.

Source: authors' own elaboration on the basis of the literature review..

tion, the ability to deal with complexity, the ability to develop and implement strategies, and the ability to apply future studies' methodologies. In turn, by analyzing the above table in columns, it can be noted, that such general competences as: analyzing data or information, critical thinking, inductive reasoning, interpreting the meaning of information and conveying it to others, reflexive capacity, and thinking creatively are necessary to implement most of the specific competences. In order to reduce the complexity of the research, twelve general competences were further analyzed.

\section{Validating Competences through a Survey of University Students, Academics, and Business Representatives (Entrepreneurs)}

In order to verify and validate the twelve competences (Figure 2), a survey in the form of a questionnaire was submitted to all target groups addressed by the project. The aim of the survey was: a) to have respondents rank the twelve compe- tences according how they are needed in order to deal with the uncertainties of the future and b) to understand and identify the educational needs of entrepreneurs, university students, and academics as the framework when designing adequate online courses to introduce the field of futures studies.

The survey process took over six weeks (from November until mid-December 2017) and was conducted in all four project countries: Germany, Italy, Poland, and Spain. Each project country aimed to reach the following number of respondents:

- Students - 80;

- Academics - 24;

- Entrepreneurs - 16 .

The number of respondents was based on the research assumptions envisaged in the feasibility study of the beFore project and the budget allocated for the survey.

The authors did not assume that the sample would be representative of such a wide group of respondents due to the costs of the research, but rather sought to obtain a general 


\section{Box 1. A Pilot List of 39 Competences}

1. The ability to define, identify, and analyze trends within the micro- and macroenvironment of a company

2. The ability to find and interpret weak signals of change and disruptions (wild cards and abnormal phenomena)

3. The ability to identify factors influencing the use of strategic foresight by companies

4. The ability to define measurable goals to create a preferred future vision for the organization

5. The ability to work in teams

6. The ability to possess guerilla skills to challenge assumptions

7. The ability to gather, analyze processes, and interpret data (also using IT tools)

8. The ability to act proactively (autonomous strategic behavior, enterprising spirit)

9. Reflexive capacity

10. The ability to develop measurement systems to control innovation initiatives and strategic direction

11. Coaching skills

12. The ability to communicate internally, on an interdisciplinary basis, and with stakeholders

13. The ability to manage projects

14. The ability to develop organizational resilience

15. The ability to run strategic foresight within an organization

16. Systemic thinking

17. Risk-taking capability

18. The ability to manage change and uncertainty (also dynamic capability)

19. The ability to build networks both internally and externally

20. The ability to deal with complexity

21. Understanding dangers of efficiency

22. The ability to develop and implement strategies

23. Time competence (time-organizing skills, utilizing real-time, making optimal use of the diversities of time, appreciation of slow life, developing futures thinking, and futures consciousness)

24. The ability to think out of the box

25. The ability to transform new ideas into business practices

26. Capacity for design thinking

27. The ability to implement the scenario approach within an organization

28. The ability to create an organizational vision (both collective and individual)

29. The ability to identify goods or services that people want

30. Accepting incompleteness of knowledge

31. Non-linear thinking

32. The ability to apply various future studies' methodologies

33. The ability to implement selected methods of technology management (technology assessment, technology mapping, technology life cycle, prioritisation, technology audit, and roadmapping)

34. The ability to perceive unmet consumer needs

35. The ability to look for products that provide real benefit

36. Seizing high-quality business opportunities

37. Maximizing results in resource allocation

38. Seeing the big picture

39. Tolerance of ambiguity

Source: [Kononiuk et al., 2017].

opinion on the respondents' preferences regarding competences. All in all, the project consortium managed to reach 190 students, 75 academics, and 81 entrepreneurs in the four countries (346 respondents in total). The consortium chose to follow a non-probability sampling method (purposive sampling) to achieve a maximum of variety throughout university faculties and entrepreneurial branches. The survey included quantitative as well as qualitative questions. The questionnaire was divided into three parts: respondents rated the twelve competences according (I) to their present educational and vocational situation; (II) to their expected future needs in their working life, and (III) general information to obtain, for example, an overview of the respondents' knowledge of the field [beFORE, 2018].?

In part I and II the ranking of the competences were evaluated quantitatively through the use of a scale from " 1 " - the maxi- mum ranking to " 6 " - the minimum. The details of the survey evaluation process go beyond the scope of this paper and can be reviewed in [beFORE, 2018].

The qualitative questions were involved in part II and III. In II they asked the respondents to reflect on their future professional situation and how it could change in 10-15 years' time (including global or personal changes, challenges, goals, and job titles). In part III of the questionnaire, the respondents were asked to clarify how familiar they were with the terms "foresight" and "futures literacy" and which online learning methods they prefer.

"Adaptability/Flexibility", "Critical Thinking", "Thinking Creatively", "Analyzing Data or Information", "Developing Objectives and Strategies", and "Making Decisions and Solving Problems" (Table 5) were the six highest ranking competences of the twelve assessed in the survey.

\footnotetext{
The qualitative nature of the survey (many open, thought-provoking questions) resulted in a relatively high number of personal or telephone interviews when executing the survey (it was specifically the case with the entrepreneur group).
} 
1. To define and identify trends within the micro- and macro-environment of the (company) organization

la. To define and identify trends within the microand macro-environment of the company

2a. To find (to seek?) weak signals of change and disruptions (wild cards and abnormal phenomena)

$2 b$. To interpret weak signals of change and disruptions (wild cards and abnormal phenomena)"

4b. To set / create preferred future vision for the organization

${ }^{*} 6$. To possess guerrilla skills to challenge

assumptions

8. To act proactively (autonomous strategic behavior, enterprising spirit)

9. To have reflexive capacity

10. To develop measurement system to control innovation initiatives and strategic direction

12a-c. To communicate internally, interdisciplinary, with stakeholders

${ }^{\star} 18 \mathrm{a}$. To manage change and uncertainty (also dynamic capability)

${ }^{*} 18 \mathrm{~b}$. To manage [(new) to communicate?] change and uncertainty

$19 a+b$. To build networks internally and externally

${ }^{*} 20$ b. To understand complexity

22a. To develop strategies

23c. To understand diversities of time

*26. To have the capacity for design(erly) thinking

27. To implement scenario approach within organization

$28 \mathrm{~b}$. To create an individual vision

$28 \mathrm{c}$. To collectively develop a vision within / for an organization

30. To accept incompleteness of knowledge

31. To have the capability to engage in nonlinear

thinking

39. To tolerate ambiguity

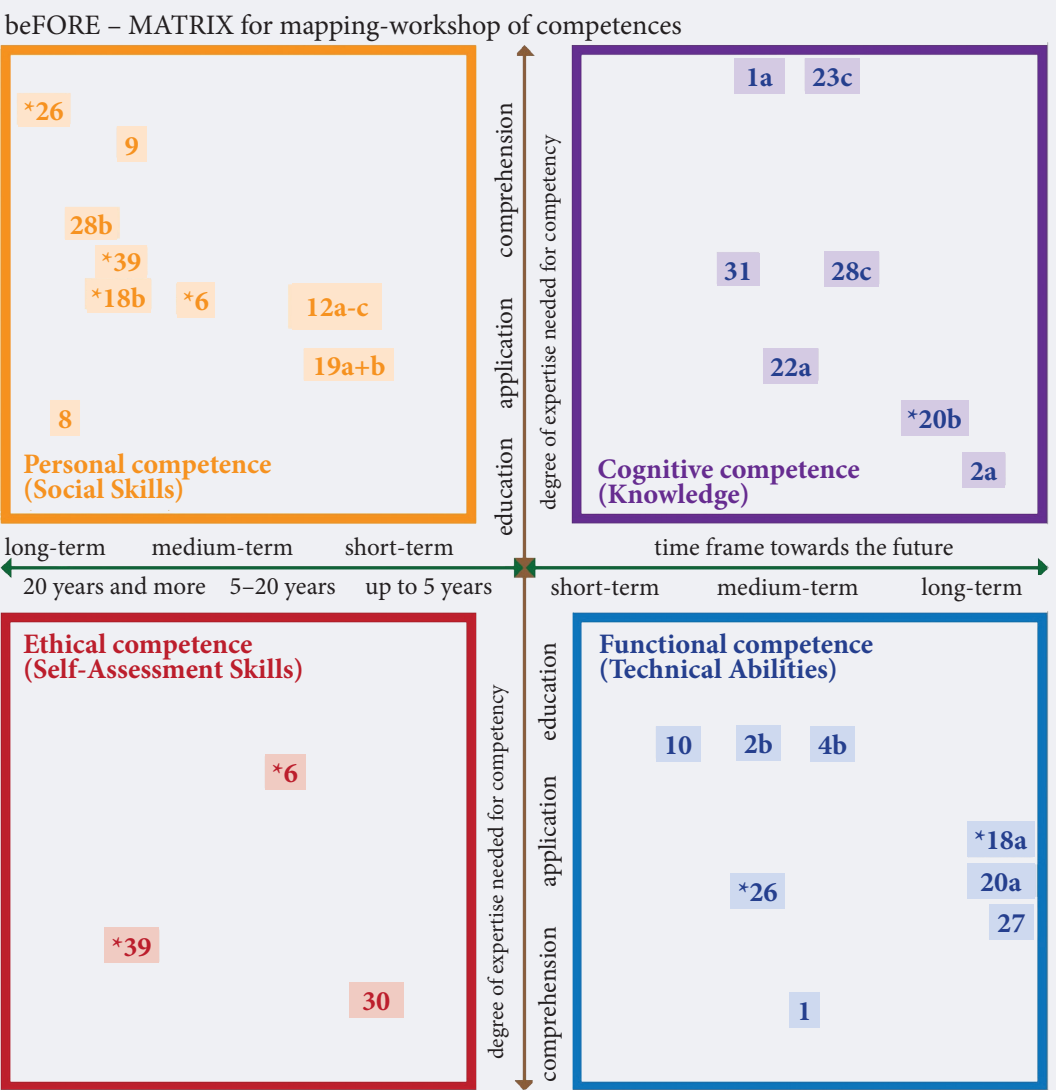

Source: authors.

Worth emphasizing is the fact that significant differences between both different countries and target groups were not noticed. In studies on education for sustainable development, the data showed similar results. There the respondents emphasized the relevance of competences that support the shaping and transformation of future developments [Rieckmann, 2011]. This confirms the results in the beFORE project survey and the relevance of future-oriented competences that go beyond analytical skills to include critical thinking, adaptability, and creative skills.

Slightly larger differences between the target groups (academics vs. students vs. entrepreneurs) occurred in the case of the open questions, especially those related to personal achievements, aspirations, and visions of the future. As the target groups differ in age and are at different stages of life, this was a rather expected outcome. For example, to the question about the changes that were expected to have the greatest impact upon the respondents' future jobs, students expected the greatest changes in their personal life (i.e., starting of a family, migration, etc.) $58 \%$ compared to $32 \%$ in the case of academics and $27 \%$ in the case of entrepreneurs. Commonalities in the target groups were found in their expectations regarding changes that will have the greatest impact upon future working conditions are: 'Technological development of discoveries from scientific research" (46\% of all respondents and more than 100 specific examples provided) [beFORE, 2018].

The results of the assessment of the twelve 'future-oriented' competences (Figure 2) and the personal need to improve them (now and in the future) was one pillar in the process of creating the e-learning courses. The other pillar was from the qualitative evaluation and assessing the relevant topics: the readiness to establish one's own company in the future or the awareness of foresight or futures thinking, to name just a few. Taking into consideration the research sample $(n=346$ respondents) and the survey's high descriptive value, the extensive survey was worthwhile. The consortium received a better understanding of the target groups' needs and was able to build a flexible structure for the e-learning platform that is appealing to all learners.

\section{Producing the Online Educational Offer Research result as the foundation for developing the pedagogical structure}

The main conclusions and recommendations arising from the needs analysis gave insights allowing one to find an adequate pedagogical approach, structures, as well as learning objectives, suitable didactic tools, and methods. The survey did reveal that most survey participants favor studying case studies and projects that demonstrate how to apply foresight and futures literacy methodologies in real life. The preference for case studies in online courses is also confirmed by e-learning experts [Clark, Mayer, 2016]. Hence, the use of the competence-based approach has become an important aspect of reflections on course content design and didactical choices. Taking into consideration the pedagogical approach, de Haan [de Haan, 2010] highlights the importance of arrangements 


\section{Table 2. After Mapping Exercise: List of 55 Items (39 Rephrased Competences)}

Competences

01a. To define trends within the micro- and macro-environment of the company

Mapped as

01b. To identify trends within the micro- and macro-environment of the company

$\mathrm{C} / \mathrm{L} / \mathrm{U}$

01c. To analyze trends within the micro- and macro-environment of the company

$\mathrm{C} / \mathrm{L} / \mathrm{U}$

02a. To find (to seek?) weak signals of change and disruptions (wild cards and abnormal phenomena)

$\mathrm{F} / \mathrm{S} / \mathrm{A}$

02b. To interpret weak signals of change and disruptions (wild cards and abnormal phenomena)"

$\mathrm{C} / \mathrm{L} / \mathrm{T}$

03. To identify factors influencing the use of strategic foresight by companies

$\mathrm{F} / \mathrm{M} / \mathrm{A}$

04. To define measurable goals to create a preferred future vision for the organization

F/S/A

05 . To work in teams

$\mathrm{F} / \mathrm{M} / \mathrm{A}$

$\mathrm{P} / \mathrm{S} / \mathrm{A}$

06. To possess guerrilla skills to challenge assumptions

$\mathrm{P}-\mathrm{E} / \mathrm{M} / \mathrm{A}$

07a. To gather data (also using IT tools)

07b. To analyze and process data (also using IT tools)

F/S/A-U

$\mathrm{C} / \mathrm{S} / \mathrm{A}$

07c. To interpret data (also using IT tools)

$\mathrm{C} / \mathrm{S} / \mathrm{U}$

08. To act proactively (autonomous strategic behavior, enterprising spirit)

P/L-M-S/T

09 . To have reflexive capacity

P/L-M-S/U

10. To develop a measurement system to control innovation initiatives and strategic direction

F/S-M/A

11. To possess coaching skills

F-P/ M/T-A-U

12a-c. To communicate internally, in an interdisciplinary manner, with stakeholders

$\mathrm{P} / \mathrm{S}-\mathrm{M} / \mathrm{A}$

13. To manage projects

F/S/A

14. To develop organizational resilience

F/L/E

15. To run strategic foresight within an organization

F/M-L/A

16. To understand systemic thinking

$\mathrm{C} / \mathrm{L} / \mathrm{U}$

17. To have risk-taking capability

$\mathrm{P} / \mathrm{S} / \mathrm{T}$

18a. To manage change and uncertainty (also dynamic capability)

F/S-L/A

19a-b. To build networks internally and externally

20. To deal with complexity

21. To understand the dangers of efficiency

22a. To develop strategies

22b. To implement strategies

23a. To have time-organizing skills

$\mathrm{P} / \mathrm{M} / \mathrm{A}$

F/M/A

$\mathrm{E} / \mathrm{M} / \mathrm{U}$

$\mathrm{C} / \mathrm{M} / \mathrm{A}$

F/S/A

F/S/A

23b. To utilize real-time

F/S/A

23c. To make optimal use of the diversities of time

$\mathrm{C} / \mathrm{M}-\mathrm{L} / \mathrm{U}$

23d. To appreciate a slow life

$\mathrm{E} / \mathrm{S} / \mathrm{U}$

$23 \mathrm{e}-\mathrm{f}$. To develop futures thinking and futures consciousness

24. To think out of the box

25. To transform new ideas into business practices

26. To have the capacity for design thinking

27. To implement the scenario approach within an organization

28a. To create an organizational vision

28b. To create an individual vision

$28 \mathrm{c}$. To collectively develop a vision within / for an organization

$\mathrm{C} / \mathrm{L} / \mathrm{U}$

$\mathrm{P} / \mathrm{L} / \mathrm{U}$

$\mathrm{F} / \mathrm{L} / \mathrm{A}$

F-P/M-L/A

F/S-L/A

$\mathrm{C} / \mathrm{M} / \mathrm{A}$

$\mathrm{P} / \mathrm{M}-\mathrm{L} / \mathrm{A}$

$\mathrm{C} / \mathrm{M} / \mathrm{A}$

$\mathrm{C} / \mathrm{S} / \mathrm{U}$

29. To identify goods or services people want

$\mathrm{E} / \mathrm{S} / \mathrm{U}$

$\mathrm{C} / \mathrm{M} / \mathrm{A}$

31 . To have the capability to engage in nonlinear thinking

F/S/A

32. To apply various future studies' methodologies

34. To perceive unmet consumer needs

35. To look for products that provides real benefit

36. To seize high-quality business opportunities

37. To maximize results in resource allocation

38 . To see the big picture

39 . To tolerate ambiguity

Source: [Kononiuk et al., 2017]. 


\section{Table 3. The General Algorithm and Example} of the Process of Matching beFORE Competences with Corresponding $\mathrm{O}^{\star}$ NET Database Competences

\begin{tabular}{|l|l|l|}
\hline \multicolumn{1}{|c|}{$\begin{array}{c}\text { beFORE } \\
\text { competences }\end{array}$} & \multicolumn{1}{|c|}{ Explanation } & $\begin{array}{l}\text { Corresponding } \\
\text { ONET database }^{*} \\
\text { competences }\end{array}$ \\
\hline $\begin{array}{l}\text { beFORE } \\
\text { competences: } \\
01 \mathrm{a}, 02 \mathrm{~b}, 02 \mathrm{a}, 02 \mathrm{~b}, \\
06,16,27\end{array}$ & $\begin{array}{l}\text { Matching beFORE } \\
\text { competences with } \\
\text { those from O*NET } \\
\text { database (example) }\end{array}$ & $\begin{array}{l}\mathrm{O}^{*} \mathrm{NET} \\
\text { competence A } \\
\text { "systems thinking” }\end{array}$ \\
\hline $\begin{array}{l}\text { beFORE } \\
\text { competences: } \\
\mathrm{n}, \mathrm{n} 1, \mathrm{n} 2 \ldots . .\end{array}$ & $\begin{array}{l}\text { General algorithm } \\
\text { applied in the } \\
\text { matching process }\end{array}$ & $\begin{array}{l}\mathrm{O}^{*} \mathrm{NET} \\
\text { competence N }\end{array}$ \\
\hline \multicolumn{2}{|l|}{ Source: own elaboration. } \\
\hline
\end{tabular}

for the education processes and environment as factors which have an impact upon knowledge construction. He stresses that self-directed processes and self-guidance contribute to more efficient learning. At the same time, he emphasizes that competences are acquired more effectively when the learning process is embedded in a context [de Haan, 2010].

Similar expectations of the project target groups regarding the desired competences as indicated in the survey research devoted to needs analysis supported a pedagogical approach that allows shared modules for the three target groups of the project: academics, students, and business people. Nevertheless, the level of foresight knowledge and foresight literacy should be differentiated in order to meet the needs of the target groups as much as possible.
Hence, the authors of the platform decided that its concept should include, on the one hand, an introductory section on foresight issues and foresight literacy and, on the other hand, it should allow for the introduction of increasingly advanced topics and allow for a balance between theoretical knowledge and practical knowledge.

This encouraged the design of a common course structure with an e-learning architecture starting with the basic courses and adding thematic courses covering advanced material.

The idea of an e-learning platform benefits from the theories of behaviorism and cognitivism which lay the foundations for the Instructional Systems Design (ISD), which comprises nine learning phases with the aim to motivate the students [Gagné,1984; Merrill, 2002]. The phases are presented in Figure 4.

Through the implementation of the nine learning events, the newly attained knowledge and the corresponding transmission of competences are continually checked.

The authors of the article emphasize that the accumulation of various educational goals is likely to happen throughout the procedure of accommodating different competences during the acquisition of theory and practice [Gagne, Merill, 1990].

The application of nine events within the beFore e-learning platform provided an underlying framework both for the preparation and delivery of the content covering a wide range of educational objectives conveying the twelve general competences in an engaging context for every topic in the training course.

\section{Figure 3. General Competences}

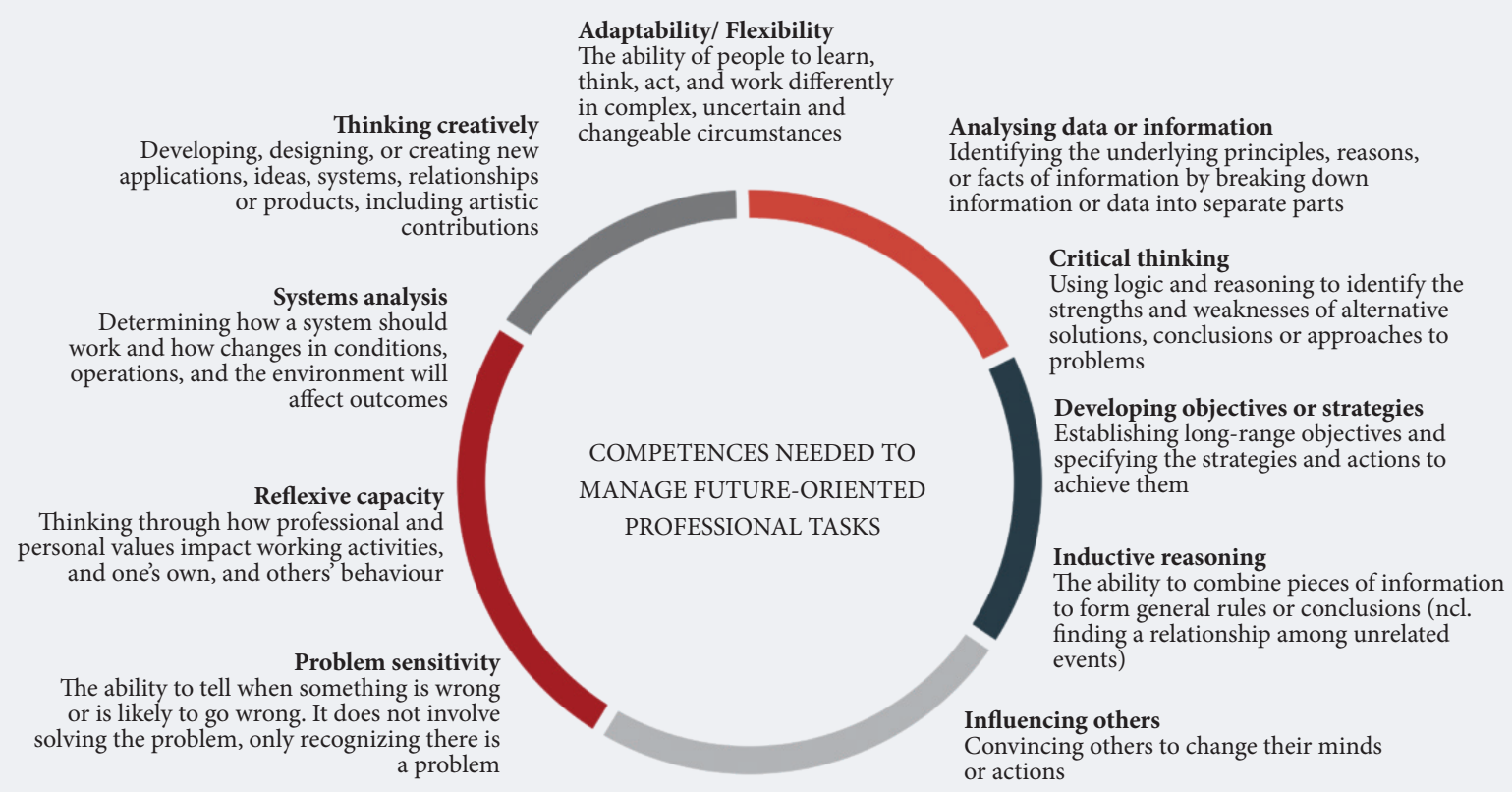

Making decisions and solving problems Analysing information and evaluating results to choose the best solution and solve problems
Interpreting the meaning of information to others

Communicating with others to translate or explain what information means and how it can be used

Source: http://futureoriented.eu/foresight-course/, accessed 18.07.2021. 


\section{Table 4. The Relationship between Specific and General Competences}

\begin{tabular}{|c|c|c|c|c|c|c|c|c|c|c|c|c|}
\hline Competences & I & II & III & IV & V & VI & VII & VIII & IX & X & XI & XII \\
\hline
\end{tabular}

1. The ability to define, identify, and analyze trends within the micro- and macroenvironment of a company

2.The ability to find and interpret weak signals of change and disruptions (wild cards and abnormal phenomena)

3. The ability to identify factors influencing the use of strategic foresight by companies

4. The ability to define measurable goals to create a preferred future vision for the organization

5. The ability to work in teams

6. The ability to possess guerrilla skills to challenge assumptions

7. The ability to gather, analyze, process, and interpret data (also using IT tools)

8. The ability to act proactively (autonomous strategic behavior, enterprising spirit)

9. Reflexive capacity

10. The ability to develop measurement systems to control innovation initiatives and strategic direction

11. Coaching skills

12. The ability to communicate internally, in an interdisciplinary manner, and with stakeholders

13. The ability to manage projects

14. The ability to develop organizational resilience

15. The ability to run strategic foresight within an organization

16. Systemic thinking

17. Risk-taking capability

18. The ability to manage change and uncertainty (also dynamic capability)

19. The ability to build networks both internally and externally

20. The ability to deal with complexity

21. Understanding the dangers of efficiency

22. The ability to develop and implement strategies

23. Time competence (time-organizing skills, utilizing real-time, making optimal use of the diversities of time, appreciation of slow life, developing futures thinking, and futures consciousness)

24. The ability to think out of the box

25. The ability to transform new ideas into business practices

26. Capacity for design thinking

27. The ability to implement the scenario approach within an organization

28. The ability to create an organizational vision (both collective and individual)

29. The ability to identify goods or services people want

30. Accepting incompleteness of knowledge

31. Non-linear thinking

32. The ability to apply various future studies' methodologies

33. The ability to implement selected methods of technology

management (technology assessment, technology mapping, technology

life cycle, prioritization, technology audit, and roadmapping)

34. The ability to perceive unmet consumer needs

35. The ability to look for products that provide real benefit

36. Seizing high-quality business opportunities

37. Maximizing results in resource allocation

38. Seeing the big picture

39. Tolerance of ambiguity

\begin{tabular}{|c|c|c|c|c|c|c|c|c|c|c|c|} 
I & II & III & IV & V & VI & VII & VIII & IX & X & XI & XII \\
\hline & $\sqrt{ }$ & $\sqrt{ }$ & & $\sqrt{ }$ & & $\sqrt{ }$ & & & & &
\end{tabular}

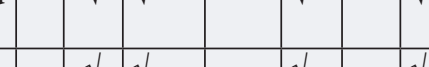

\begin{tabular}{|l|l|l|l|l} 
& $\sqrt{ }$ & $\sqrt{ }$ & & $\sqrt{ }$ \\
& $\sqrt{ }$ & $\sqrt{ }$ & & $\sqrt{ }$
\end{tabular}

\begin{tabular}{lll|l|l|l|l|l|l} 
& & $\sqrt{ }$ & $\sqrt{ }$ & & & $\sqrt{ }$
\end{tabular}

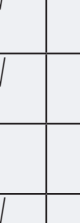

\begin{tabular}{|l|l|l|l|l|l|l|l|l|l|l|l|l|}
\hline & $\sqrt{ }$ & & $\sqrt{ }$ & & & $\sqrt{ }$ & $\sqrt{ }$ & & $\sqrt{ }$ & $\sqrt{ }$ & $\sqrt{ }$ \\
\hline & & & $\sqrt{ }$ & & $\sqrt{ }$ & $\sqrt{ }$ & $\sqrt{ }$ & & $\sqrt{ }$ & $\sqrt{ }$ & & $\sqrt{ }$ \\
\hline & & & & & $\sqrt{ }$ & & $\sqrt{ }$ & & & $\sqrt{ }$ & & \\
\hline
\end{tabular}

\begin{tabular}{|l|l|l|l}
\hline & & $\sqrt{ }$ \\
$\sqrt{ }$ & & $\sqrt{ }$ \\
& $\sqrt{ }$ &
\end{tabular}

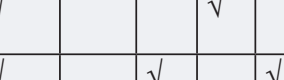

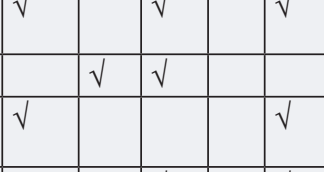

\begin{tabular}{|l|l|l|l|l|l|l|l|l|l|l|l|}
\hline & & $\sqrt{ }$ & $\sqrt{ }$ & $\sqrt{ }$ & & $\sqrt{ }$ & & & $\sqrt{ }$ & & $\sqrt{ }$ \\
\hline
\end{tabular}

\begin{tabular}{|c|c|c|c|}
\hline$\sqrt{ }$ & $\sqrt{ }$ & $\sqrt{ }$ & $\sqrt{ }$ \\
\hline$\sqrt{ }$ & $\sqrt{ }$ & $\sqrt{ }$ & $\sqrt{ }$ \\
\hline$\sqrt{ }$ & $\sqrt{ }$ & $\sqrt{ }$ & $\sqrt{ }$ \\
\hline & & & \\
\hline
\end{tabular}

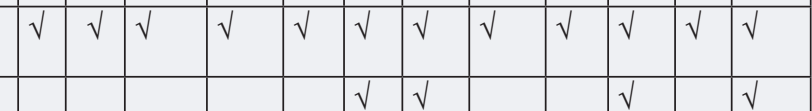

$\begin{array}{llllllllllllllll}\sqrt{ } & \sqrt{ } & \sqrt{ } & \sqrt{ } & \sqrt{ } & & \sqrt{ } & \sqrt{ } & \sqrt{ } & \sqrt{ } & \sqrt{ } & \sqrt{ }\end{array}$

\begin{tabular}{lll|l|l|l|l|l|l|l|l|l|l}
$\sqrt{ }$ & $\sqrt{ }$ & $\sqrt{ }$ & $\sqrt{ }$ & $\sqrt{ }$ & $\sqrt{ }$ & $\sqrt{ }$ & $\sqrt{ }$ & $\sqrt{ }$ & $\sqrt{ }$ & $\sqrt{ }$ & $\sqrt{ }$
\end{tabular}

\begin{tabular}{|l|l|l|l|l|l|l|l|l|l|l|l|} 
& $\sqrt{ }$ & $\sqrt{ }$ & & & & & $\sqrt{ }$ & & $\sqrt{ }$ & $\sqrt{ }$ \\
\hline
\end{tabular}

\begin{tabular}{|l|l|l|l|l|l|l|l|l|l|l|l|}
$\sqrt{ }$ & & $\sqrt{ }$ & & & & & & & $\sqrt{ }$ & & $\sqrt{ }$ \\
$\sqrt{ }$ & $\sqrt{ }$ & $\sqrt{ }$ & & & $\sqrt{ }$ & $\sqrt{ }$ & & & $\sqrt{ }$ & & $\sqrt{ }$ \\
\hline$\sqrt{ }$ & $\sqrt{ }$ & $\sqrt{ }$ & $\sqrt{ }$ & $\sqrt{ }$ & & $\sqrt{ }$ & $\sqrt{ }$ & $\sqrt{ }$ & $\sqrt{ }$ & $\sqrt{ }$ & $\sqrt{ }$ \\
\hline$\sqrt{ }$ & $\sqrt{ }$ & $\sqrt{ }$ & $\sqrt{ }$ & $\sqrt{ }$ & & $\sqrt{ }$ & & $\sqrt{ }$ & $\sqrt{ }$ & $\sqrt{ }$ & $\sqrt{ }$ \\
\hline
\end{tabular}

\begin{tabular}{|l|l|l|l|l|l|l|l|l|l|l|l|}
$\sqrt{ }$ & $\sqrt{ }$ & $\sqrt{ }$ & $\sqrt{ }$ & $\sqrt{ }$ & & $\sqrt{ }$ & & $\sqrt{ }$ & $\sqrt{ }$ & $\sqrt{ }$ & $\sqrt{ }$ \\
$\sqrt{ }$ & $\sqrt{ }$ & $\sqrt{ }$ & $\sqrt{ }$ & $\sqrt{ }$ & $\sqrt{ }$ & $\sqrt{ }$ & & $\sqrt{ }$ & $\sqrt{ }$ & $\sqrt{ }$ & $\sqrt{ }$ \\
\hline
\end{tabular}

Note: I - Adaptability/Flexibility; II — Analyzing data or information; III — Critical thinking; IV — Developing objectives or strategies; V - Inductive reasoning; VI - Influencing others; VII - Interpreting the meaning of information and conveying it to others; VIII - Making decisions and solving problems; IX - Problem sensitivity; X — Reflexive capacity; XI — Systems analysis; XII — Thinking creatively

Source: own elaboration. 
Table 5. Comparison of the Rankings of Competences Needed in the Present and the Future to Manage Future-Oriented Tasks Combined with the Need for Improvement Both in the Present and Future

\begin{tabular}{|l|l|l|l|}
\hline \multirow{2}{*}{ No } & \multicolumn{3}{|c|}{ Importance and need for improvement } \\
\cline { 2 - 4 } & In the Present (Q1-Q2 Average) & In the Future (Q5-Q6 Average) & $\begin{array}{l}\text { Average of the Present and the Future } \\
\text { (Q1-Q2 and Q5-Q6 Average) }\end{array}$ \\
\hline 1 & Critical Thinking & Adaptability/Flexibility & Adaptability/Flexibility \\
\hline 2 & Adaptability/Flexibility & Critical Thinking & Critical Thinking \\
\hline 3 & Thinking Creatively & Thinking Creatively & Thinking Creatively \\
\hline 4 & Analyzing Data or Information & Developing Objectives and Strategies & Analyzing Data or Information \\
\hline 5 & Developing Objectives and Strategies & Influencing Others & Developing Objectives and Strategies \\
\hline 6 & Making Decisions and Solving Problems & Making Decisions and Solving Problems & Making Decisions and Solving Problems \\
\hline Source: own elaboration. & & \\
\hline
\end{tabular}

In developing the course, the authors followed Snelbecker's suggestion that the content presented in practice-based learning should create value for the specific situation in which the learning takes place [Snelbecker, 1983] (cited by [Ertmer, Newby, 2013, p. 8]).

\section{The Architecture and Content of the E-Learning Platform}

Further on, the learning objectives were formulated to meet the needs of the target groups and convey the twelve competences needed to become futures literate and attain knowledge in foresight. The following are examples from a list that was the result of an internal exercise to collect and cluster all relevant learning objectives aimed at acquiring knowledge in foresight and futures studies. In the process, topics from foresight and futures studies as well as entrepreneurial aspects were considered and evaluated (Table 6). The resulting training material is intended to encourage active engagement with the content and to illustrate it with practical examples.

The framework of the platform was a superordinate division organizing the content into a total of seven modules from fundamental principles to specializing in futures thinking. Though the recommendation to the learner is to follow the platform's logic, the courses' modules can be entered at any stage offering the learners the flexibility to create a highly individualized learning experience.

The first four modules - "Futures Basic Course" (FBC) - form a unit to introduce the foundation of futures studies such as definitions, perceptions of future images and developments, systems thinking as well as well-known methods used in the field. The modules of the "Futures Advanced Course" (FAC) correspond to the target group differences as defined in the process of the project through the survey (Figure 5).

All modules are thematically set up and divided into lessons which consist of topics representing a self-contained learning unit readily available according to the learner's interest. Thus, the individual can acquire the contents of a module or a lesson with selected topics according to their level of knowledge or can repeat and deepen existing knowledge. Students are empowered to determine the course of their personal learning journey by choosing the content at their discretion. Directions are given through examples of learning paths offered on the platform. ${ }^{8}$
The uniqueness of the course is manifested by its flexibility in choosing the learning paths and by introducing in one place a great variety of subjects that deal with the issues of foresight and futures literacy. The course topics are not only about the theory and practice of future studies. The course also deals with issues related to entrepreneurship, in relation to which, in the opinion of the authors, foresight studies form a supportive role. To the authors' knowledge, the course offered is currently the most extensive free, open access course offered in the field of foresight and futures literacy.

\section{Set up and Challenges of the Educational Offer}

For learners who have no previous knowledge in this area, it is recommended that they work through most of the topics of the first four modules of the FBC. These modules cover all relevant topics in the areas of future orientation, futures studies, and corporate foresight. The FBC introduces the field and intends to generate interest in topics related to futures and foresight and create a knowledge base for all learners. Since an important aspect of futures literacy is to reflect on and understand the concept of futures [Bell, 1997], the first module in particular focuses on the competences of adaptability/flexibility, critical thinking, and reflexive capacity.

\section{Figure 4. Nine Learning Phases}

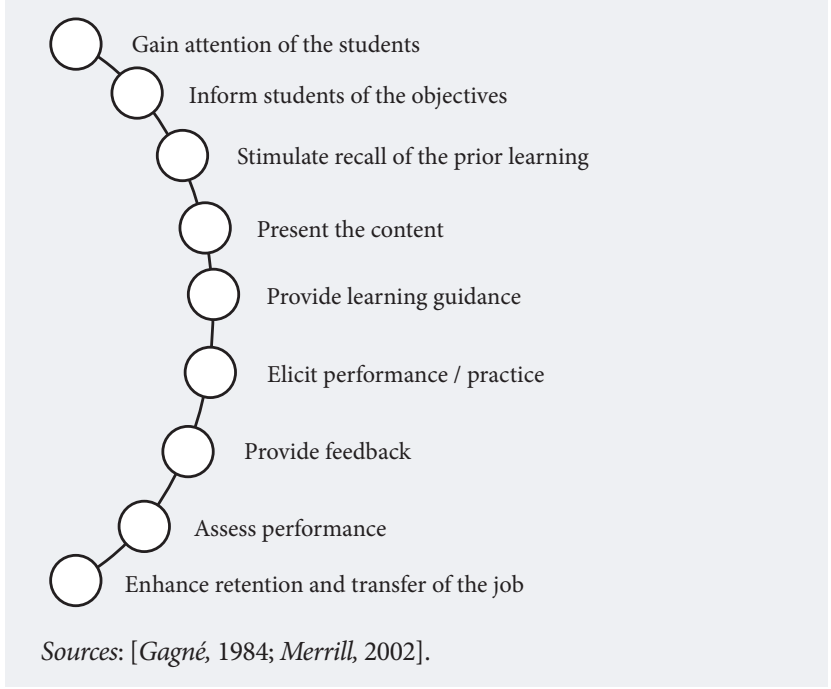

${ }_{8}^{8}$ http://futureoriented.eu/foresight-course/, accessed 22.06.2021. 
Table 6. Exemplary Learning Objectives and Topics in Relation to the Twelve Competences for Future-Oriented Entrepreneurs

\begin{tabular}{|c|c|c|c|}
\hline $\begin{array}{l}\text { Module/ } \\
\text { Lesson/Topic }\end{array}$ & Learning objective & Content (short description) & Competences \\
\hline $\begin{array}{l}\mathrm{M} 1 / \mathrm{L} 2 / \mathrm{T} 1,3,4 \\
\mathrm{M} 4 / \mathrm{L} 3 / \mathrm{T} 1-3\end{array}$ & $\begin{array}{l}\text { Be able to think strategically } \\
\text { on a long-term basis by using } \\
\text { the most well-known tools in } \\
\text { entrepreneurship design and } \\
\text { innovation management. }\end{array}$ & $\begin{array}{l}\text { Explanation of the differences between normative } \\
\text { and explorative scenarios; Time makes a difference }\end{array}$ & $\begin{array}{l}\text { Critical thinking } \\
\text { Developing Objectives and } \\
\text { Strategies } \\
\text { Problem Sensitivity }\end{array}$ \\
\hline $\mathrm{M} 2 / \mathrm{L} 1 / \mathrm{T} 1-3$ & $\begin{array}{l}\text { Be able to monitor and evaluate } \\
\text { changes in the external } \\
\text { environment, discover new } \\
\text { directions and move between } \\
\text { megatrends and trends. }\end{array}$ & Differences between uncertainty and risk & $\begin{array}{l}\text { Analyzing Data or } \\
\text { Information } \\
\text { Adaptability/ Flexibility } \\
\text { Making Decisions and } \\
\text { Solving Problems }\end{array}$ \\
\hline $\mathrm{M} 6 / \mathrm{L} 4 / \mathrm{T} 1-4$ & $\begin{array}{l}\text { Be able to use methods of futures } \\
\text { studies in their research as well as } \\
\text { practical templates to convey the } \\
\text { ideas to students }\end{array}$ & $\begin{array}{l}\text { In the sense of FS becoming an accompanying social } \\
\text { science course. Toolbox for academia to be used with } \\
\text { their students to reflect on how their work or their } \\
\text { future work or the results of it affect technology, } \\
\text { competition, ecology, society, and have an impact. }\end{array}$ & $\begin{array}{l}\text { Adaptability/Flexibility } \\
\text { Thinking Creatively } \\
\text { Reflexive Capacity }\end{array}$ \\
\hline
\end{tabular}

For example, in the beFORE educational offer, participants are asked in Module 1 Lesson 1 to think of their personal ideas of the future. They receive thought provoking questions and are encouraged to use a learning diary. Later in this module, students are introduced to the concept of multiple futures as well as organizational and global futures. To reinforce the knowledge in the lessons, the learner will do assignments and quizzes to practice the theory. Table 7 provides an overview of content of the FBC and FAC.

The flexible structure of the platform and the opportunity to acquire knowledge independently takes into account the different interests, life circumstances, levels of experience, and time contingents of learners. At the same time, it requires a high degree of self-assessment and intrinsic motivation for the subject. The first iteration through a pilot launch of the e-learning platform was well received by representatives of all three target groups in all four project partner countries. A certain inconsistency of the training material was criticized. This was taken up in the phase of qualitative upgrading and the contents were revised as a result. The platform can be understood as a well-crafted prototype, which focuses on content and uses simpler interactive methods such as the learning diary. Furthermore, the e-learning platform is without instructional support and therefore requires the autodidactic abilities of all learners. In particular, the lack of support and the prerequisite of personal motivation can lead to the discontinuation of online-based learning [Johnson, Brown, 2017]. The project ended in December 2019, but the e-learning platform

\section{Figure 5. Course Architecture of the beFORE e-Learning Platform}

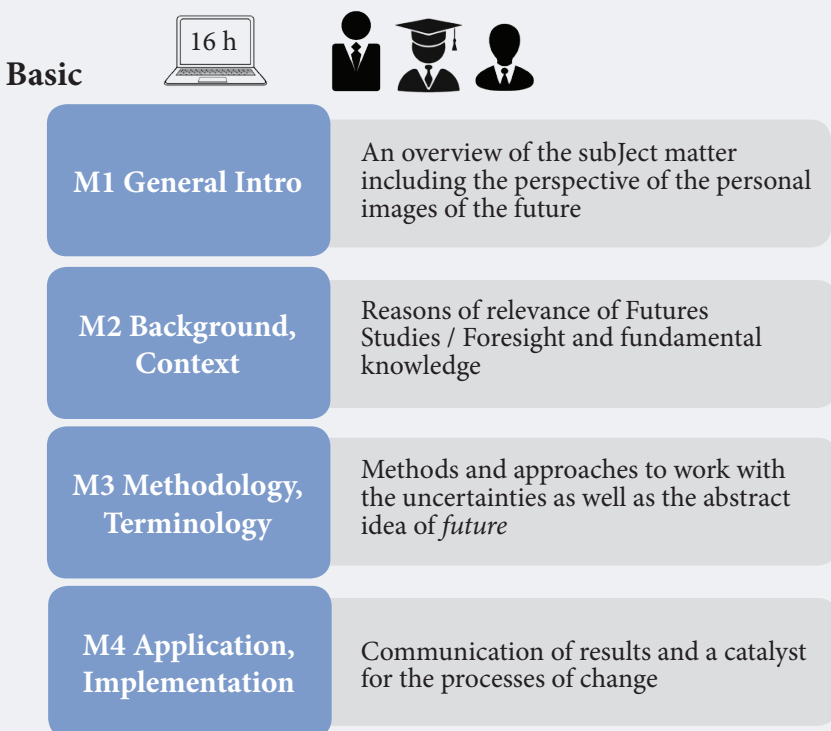

\begin{tabular}{|c|c|c|}
\hline \multirow{2}{*}{ Advanced } & \multirow[b]{2}{*}{$\begin{array}{l}\text { Business development, } \\
\text { professional development }\end{array}$} & \multirow[b]{2}{*}{$+4 \mathrm{~h}$} \\
\hline & & \\
\hline $\begin{array}{c}\text { M7 ... } \\
\text { in Management } \\
\text { and Practice }\end{array}$ & $\begin{array}{l}\text { Usability for business / } \\
\text { organizational environments and } \\
\text { in management }\end{array}$ & \\
\hline \multirow{3}{*}{$\begin{array}{l}\text { M6 ... in Research } \\
\text { and Studies }\end{array}$} & Research and teaching practice & $+6 \mathrm{~h}$ \\
\hline & $\begin{array}{l}\text { Applicability within other } \\
\text { disciplines for research } \\
\text { and education }\end{array}$ & \\
\hline & $\begin{array}{l}\text { Career path, professional } \\
\text { development }\end{array}$ & $+8 \mathrm{~h}$ \\
\hline $\begin{array}{l}\text { M5 ... in Learning } \\
\text { and Practice }\end{array}$ & $\begin{array}{l}\text { Usability for the career path, } \\
\text { acquisition of future-oriented skills } \\
\text { for the labour market }\end{array}$ & \\
\hline
\end{tabular}


Table 7. Brief Overview of the Course Modules

\begin{tabular}{|c|c|}
\hline Module & Description / aim \\
\hline \multicolumn{2}{|l|}{ Basic modules } \\
\hline $\begin{array}{l}\text { Module 1. General } \\
\text { introduction to futures } \\
\text { studies }\end{array}$ & $\begin{array}{l}\text { An introduction to the concept of the future and futures; } \\
\text { An overview of the field of futures research and strategic foresight; } \\
\text { - Insight into the different perspectives on the future }\end{array}$ \\
\hline $\begin{array}{l}\text { Module } 2 \text {. Background and } \\
\text { relevance of foresight }\end{array}$ & $\begin{array}{l}\text { A first overview of areas of application; } \\
\text { - Explanation of basic knowledge from the field of system theory relevant for foresight work }\end{array}$ \\
\hline $\begin{array}{l}\text { Module 3. Methodology } \\
\text { and terminology in futures } \\
\text { studies }\end{array}$ & $\begin{array}{l}\text { - An overview of the methods and tools needed to work with the abstract notions of future / } \\
\text { uncertainty; } \\
\text { - putting concepts into context }\end{array}$ \\
\hline $\begin{array}{l}\text { Module } 4 \text {. Fields of } \\
\text { application of futures } \\
\text { studies in the economy }\end{array}$ & $\begin{array}{l}\text { Introduction to specific methods; communication and handling of results; } \\
\text { - Application of the results based on a design process }\end{array}$ \\
\hline \multicolumn{2}{|l|}{ Advanced modules } \\
\hline Module 5 (for students) & Usability for future career paths, acquisition of skills relevant for a future job market \\
\hline Module 6 (for academics) & Possible use within their discipline in research and teaching \\
\hline $\begin{array}{l}\text { Module } 7 \text { (for } \\
\text { entrepreneurs) }\end{array}$ & The applications for businesses and the organizational environment in management as well as for start-ups \\
\hline
\end{tabular}

continues to be accessible in accordance with the open access principle. The challenges remain that there is no immediate learning support, facilitation, or monitoring of learning success. In future iterations, a forum for knowledge exchange and further interactivity may be needed; for example, online coaching services. Nonetheless, the response to the platform has been positive and is available for use by educators in entrepreneurship, management, or futures studies.

\section{Summary and Discussion}

The biggest challenge when developing the course was related to the fulfillment of learning needs (related to futures thinking) of the three different target groups that the course was supposed to cater to: the academics and students and the business professionals (any working individual interested in enhancing future-orientated skills).

We managed to do so by:

- Successfully identifying key competences - sought-for by the target groups -which address the thematic gaps in the entrepreneurial education and business/professional practice related to future-orientation and futures literacy;

- Efficiently translating the missing competences into the curriculum of an open access online course composed of self-standing basic and advanced course modules as well as three recommended learning paths for each target group.

Based on the undertaken literature review and the results of our own research, we highlight how those methodologies, concepts, and methods in the futures studies field fill the competence gap, complement entrepreneurship education, and enrich business practice. In particular, these concepts help to shift focus from economic models of financial evaluation [Ratcliffe, Ratcliffe, 2015], they facilitate the process to go beyond rational forecasting and managerial economics [Fontela, 2006] that result in cultivating an engineering management mindset [Hurst, 2014]. We agree that the inclusion of foresight and futures literacy topics and approaches into the learning journeys of students and professionals expands their perception of the concepts of incidental externalities and business durability [Ratcliffe, Ratcliffe, 2015], enhances their sustainable global thinking, systems thinking [Postma, Yeoman, 2021], and cross-disciplinary thinking. It also deepens the discussion about humanistic and scientific trends [Roos, 2014].

We believe that awareness of the possibility of futures analysis and the context that enables the development of future-oriented competences are extremely important. The results presented by [Jafari-Sadeghi et al., 2019] show that higher levels of education or knowledge in a country enhances foresight competencies.

Based on undertaken research, we illustrate how general concepts and methods of the futures studies and foresight field enrich and complement business and entrepreneurship education and enhance specific competences (Table 8).

The proposed changes in entrepreneurship curricula and business practice - toward which our research contributes should allow us to "develop new understandings of how intuition and reason can work together especially in the service of creativity and innovation" [Hurst, 2014]. The aim of such a transformation of entrepreneurship education would be "to enhance the dominant paradigm of strategy building among organisations, which rests on the classical, rational approach of deliberate planning with more emergent and creative ways" [van der Laan, 2010].

The above is complemented by the World Bank study on Entrepreneurship Education and Training Programs around the world, which reports that entrepreneurs cite mindsets and skills as a potential constraint to entrepreneurial opportunity and success [Valerio et al., 2014, pp. 20-21]. Therefore, the main objective of our research was to prototype an open online educational platform that would help individuals to become more futures literate.

Prior to the design of the course structure, we had to agree upon a pedagogical strategy and the didactical approach. In educational sciences, they are the foundation of understanding how students acquire knowledge and have been applied in designing learning experiences. Starting from the premise that although technology and media for learning is changing various ways of how to obtain knowledge, how people learn 
Table 8. Augmentation of Business and Entrepreneurship Education with Futures Studies Education Offer

\begin{tabular}{|c|c|c|}
\hline \multicolumn{2}{|c|}{ What is being taught } & What is missing \\
\hline Business management education & $\begin{array}{l}\text { Entrepreneurship } \\
\text { education and training }\end{array}$ & $\begin{array}{l}\text { Futures Studies and } \\
\text { Strategic Foresight }\end{array}$ \\
\hline Corporate management & Entrepreneur Development & Sustainable development \\
\hline $\begin{array}{l}\text { Leadership and Organizational Theory } \\
\text { Corporate Finance and Risk } \\
\text { Management } \\
\text { Managerial Economics }\end{array}$ & $\begin{array}{l}\text { Entrepreneurship Theory and principles } \\
\text { Financial literacy } \\
\text { Entrepreneurship awareness and socio- } \\
\text { emotional skills }\end{array}$ & $\begin{array}{l}\text { Organizational foresight theory and methods } \\
\text { Systems analysis } \\
\text { Societal / Environmental impacts of innovations }\end{array}$ \\
\hline \multicolumn{3}{|c|}{ Acquired competences relevant for Business and professional practice } \\
\hline \multicolumn{2}{|c|}{$\begin{array}{l}\text { Strategic planning } \\
\text { General business skills (i.e. sales, marketing, bookkeeping) }\end{array}$} & $\begin{array}{l}\text { Long-term orientation } \\
\text { Futures thinking/ Futures Literacy }\end{array}$ \\
\hline
\end{tabular}

has not tremendously changed [Ertmer, Newby, 2013]; we focused on the future-oriented competences, which became the foundation in generating the content for the e-learning platform.

\section{Limitations and Further Research}

In the context of the undertaken research, it needs to be underlined that it was not our aim to develop or update the occupational standards of a futurist, researcher, or an entrepreneur as such. Neither was the online futures literacy course, which was created as a result of our research, to provide students, researchers, or entrepreneurs with the full qualifications of a futurist. On the other hand, the research team aimed to identify the gaps within the competences of the aforementioned target groups that relate to future analysis and design an online course, which would address these gaps. From this perspective our research aim - of equipping students, teachers, researchers, or entrepreneurs with additional foresight-like skills that would complement their main professional competences - was met.

The results obtained contribute to the discussion on pedagogical strategies that might be undertaken in the area of futures literacy and also set a good e-learning practice example that could serve as a guide in entrepreneurship and futures studies education to absorb methods and the competences for a futures literate mindset.

The main learning objective, which was pursued rested on the shared understanding that "... the diffusion of futures literacy, is one way of improving the capacity of individuals and organisations to: a) detect and give meaning to discontinuity, and b) thereby become more capable of initiating learning processes" [Miller, 2015].

Therefore, some of the suggested topics for further research could refer to the fundamental issues of learning processes:

- Motivation, learning behavior, and the associated question of learning success. Proposed research questions could be: What impacts the effectiveness of the individual modules, lessons, and topics as individual learning items (single topics) and as a whole? And by which target group? How does one increase the effectiveness, usability, and enjoyability for learners?

- Thematic-orientation and topics covered, and effectiveness of practical exercises embedded in the course. Proposed research questions could be: How effective are the individual modules, lessons, and topics for learners in terms of the enhancement of their capability of futures literacy? What are the recommended assessment criteria?

- Use and impact of the materials at organizations. Proposed research questions could be: Whether and to what extent the learning platform could support the advancement and evaluation of organizational future orientation? What additional interactive tools would allow for collective organizational learning?

To sum up, uncertainty on a global scale caused by the Covid-19 pandemic has only accelerated changes and developments of the digital economy and brought further advancements in technology. It certainly has triggered an enormous learning and re-learning imperative for all. It has contributed to the growth in demand for new entrepreneurship skills and resulted in greater demand for competences - such as futures thinking - that boost resilience. In the sustained adverse external conditions, we can assume that the demand for highquality yet flexible educational offers will increase dramatically. We hope that our open online educational resources, at least in part, will help individuals to learn to navigate uncertainty.

The research was carried out within the beFORE - Becoming FutureOriented Entrepreneurs in universities and companies Project funded by European Commission Erasmus + Programme - Key Action 2; Knowledge Alliances - Agreement n. 2016 - 2858 / 001 - 001 Project n. 515842-EPP-1-2016-1-PL-EPPKA2-KA. The preparation of the article on the part of Bialystok University of Technology was carried out within the WZ/WIZ-INZ/1/2019 project and was financed using Ministry of Science and Higher Education funds.

\section{References}

Alsan A. (2008) Not with a bang, but a Blink. The Futurist, 42(1), 4+. https://link.gale.com/apps/doc/A172911390/ITOF?u=fub\&sid=ITOF \&xid=3eecb5e8, accessed 15.06.2021

Andriopoulos C., Gotsi M. (2006) Probing the future: Mobilising foresight in multiple-product innovation firms. Futures 38 (1), 50-66. https://doi.org/10.1016/j.futures.2005.04.003

Arpentieva M.R., Gorelova I.V., Kassymova K.G., Lavrinenko S.V., Shumova K.A., Malinichev D.M., Simonov V.L., Kosov A.V., Garbuzova G.V., Stepanova O.P. (2020) Human Resource Management and Dynamic Capabilities of Educational Enterprises: Psychological, Social and Economic Aspects. Bulletin of National Academy of Sciences of the Republic of Kazakhstan, 1(38), 242-254. 
Baškarada S., Shrimpton D., Ng S. (2016) Learning through foresight. Foresight, 18(4), 414-433. https://doi.org/10.1108/FS-09-2015-0045.

beFORE (2018) Future-oriented individuals: Lessons learned from a competence survey (WP2 report). http://futureoriented.eu/wp-content/ uploads/wp2f.pdf, accessed 21.05.2021.

Begley C.M. (1996) Using triangulation in nursing research. Journal of Advanced Nursing, 24(1), 122-128. https://doi.org/10.1046/j.13652648.1996.15217.x

Bell W. (1997) The purposes of futures studies. The Futurist, 31(6), 42-45.

Bell W. (2009) Foundations of Futures Studies. History, Purpose, and Knowledge Human Science for a New Era (vol. 1), New Brunswick (U.S.) and London (UK): Transaction Publishers.

Bridge S. (2017) Is "entrepreneurship" the problem in entrepreneurship education? Education+ Training, 59(7-8), 740-750. https://doi. org/10.1108/ET-02-2016-0037

Chiu F.-C. (2012) Fit between future thinking and future orientation on creative imagination. Thinking Skills and Creativity, 7(3), pp. 234244. http://dx.doi.org/10.1016/j.tsc.2012.05.002

Clark B.R. (2003) Sustaining Change in Universities: Continuities in Case Studies and Concepts. Tertiary Education and Management, 9(2), 99-116. https://doi.org/10.1080/13583883.2003.9967096

Clark R.C., Mayer R.E. (2016) E-learning and the science of instruction: Proven guidelines for consumers and designers of multimedia learning. Hoboken, NJ: John Wiley \& Sons, Inc. DOI:10.1002/9781119239086

Cuhls K., Johnston R. (2008) Corporate foresight. In: Future-Oriented Technology Analysis. Strategic intelligence for an innovative economy (eds. C. Cagnin, M. Keenan, R. Johnston, F. Scapolo, R. Barre), Heidelberg, Dordrecht, London, New York: Springer, pp. 103-114. https:// doi.org/10.1007/978-3-540-68811-2_8

Dannenberg S., Grapentin T. (2016) Education for Sustainable Development - Learning for Transformation. The Example of Germany. Journal of Futures Studies, (20)3, 7-20. DOI:10.6531/JFS.2016.20(3).A7

De Haan G. (2010) The development of ESD-related competencies in supportive institutional frameworks. International Review of Education / Internationale Zeitschrift Für Erziehungswissenschaft / Revue Internationale De L'Education, 56(2-3), 315-328. https://www.jstor.org/ stable/40928675

Denzin N.K. (1989) The research act: A theoretical introduction to sociological methods (3rd ed.), New York: Routledge.

Ejdys J., Gudanowska A., Halicka K., Kononiuk A., Magruk A., Nazarko J., Nazarko Ł., Szpilko D., Widelska U. (2019) Foresight in Higher Education Institutions: Evidence from Poland. Foresight and STI Governance, 13(1), 77-89. DOI: 10.17323/2500-2597.2019.1.77.89

Ertmer P.A., Newby T.J. (2013) Behaviorism, Cognitivism, Constructivism: Comparing Critical Features from an Instructional Design Perspective. Performance Improvement Quarterly, 26(2), 43-71. DOI: 10.1002/piq.21143.

ETF (2017) Skills Foresight: Making Sense of Emerging Labour Market Trends, Turin: European Training Foundation.

European Commission (2012) European Commission, Entrepreneurship 2020 Action Plan - Reigniting the Entrepreneurial Spirit in Europe (COM (2012) 795 final), Brussels: European Commission.

Fareri S., Fantoni G., Chiarello F., Coli E., Binda A. (2020) Estimating Industry 4.0 impact on job profiles and skills using text mining. Computers in Industry, 118, 103222. https://doi.org/10.1016/j.compind.2020.103222

Fontela E., Guzmán J., Pérez M., Santos F. J. (2006) The art of entrepreneurial Foresight. Foresight, 8(6), 3-13. https://doi. org/10.1108/14636680610712496

Fuller T., Warren L., Argyle P. (2008) Sustaining entrepreneurial business: A complexity perspective on processes that produce emergent practice. International Entrepreneurship and Management Journal, 4(1), 1-17. https://doi.org/10.1007/s11365-007-0047-y

Gagné R.M. (1984) Learning outcomes and their effects: Useful categories of human performance. American Psychologist, 39(4), 377-385. https://doi.org/10.1037/0003-066X.39.4.377

Gagné R.M., Merrill M.D. (1990) Integrative Goals for Instructional Design. Educational Technology, Research and Development, 38(1), 23-30. https://doi.org/10.1007/BF02298245

Gheorghiua R., Andreescu L., Curaj A. (2016) A foresight toolkit for smart specialization and entrepreneurial discovery. Futures, 80, 33-44. https://doi.org/10.1016/j.futures.2016.04.001

Gidley J.M. (2017) Very Short Introductions, Oxford: Oxford University Press.

Grim T. (2009) Foresight Maturity Model (FMM): Achieving Best Practices in the Foresight Field. Journal of Futures Studies, 13(4), 69-79.

Gudanowska A., Kononiuk A., Dębkowska K. (2020) The application of cluster analysis for the selection of key competences of futureoriented entrepreneurs. Inzinerie Ekonomika-Engineering Economics, 31(5), 565-574.

Heinonen S., Ruotsalainen J. (2012) Toward the age of neo-entrepreneurs. World Futures Review, 4(2), 123-133. DOI: $10.1177 / 194675671200400216$

Hiltunen E. (2013) Foresight and Innovation. How Companies are Coping with the Future, London: Palgrave MacMillan.

Hines A., Gary J., Daheim C., van der Laan L. (2017) Building foresight capacity: Toward a foresight competency model. World Futures Review, 9(3), 123-141. https://doi.org/10.1177\%2F1946756717715637

Hurst D. (2014) Is Management Due for a Renaissance? Harvard Business Review, 30.05.2014. https://hbr.org/2014/05/is-management-duefor-a-renaissance, accessed 29.05.2020.

Inayatullah S. (2008) Six pillars: Futures thinking for transforming. Foresight, 10(1), 4-21. https://doi.org/10.1108/14636680810855991

Jafari-Sadeghi V., Kimiagari S., Biancone P.P. (2020) Level of education and knowledge, foresight Competency and international entrepreneurship. European Business Review, 32(1), 46-68. DOI:10.1108/EBR-05-2018-0098

Jain R.K. (2011) Entrepreneurial Competencies: A Meta-analysis and Comprehensive Conceptualization for Future Research. Vision, 15(2), 127-152. https://doi.org/10.1177/097226291101500205

Johnson R.D., Brown K.G. (2017) E-Learning. In: The Wiley Blackwell Handbook of the Psychology of the Internet at Work (eds. G. Hertel, D.L. Stone, R.D. Johnson, J. Passmore), Hoboken, NJ: Wiley, pp. 369-400. https://psycnet.apa.org/doi/10.1002/9781119256151.ch17

Jones N., O’Brien M., Ryan T. (2018) Representation of future generations in United Kingdom policy-making. Futures, 102, 153-163. https:// doi.org/10.1016/j.futures.2018.01.007

Jonsen K., Jehn K.A. (2009) Using triangulation to validate themes in qualitative studies. Qualitative Research in Organisations and Management, 4(2), 123-150. https://doi.org/10.1108/17465640910978391

Kaivo-oja J.R.L., Lauraeus I.T. (2018) The VUCA approach as a solution concept to corporate foresight challenges and global technological disruption. Foresight, 20(1), 27-49. https://doi.org/10.1108/FS-06-2017-0022

Keller K.C. (2013) Nachhaltige Innovationen gestalten. In: Zukunftsforschung im Praxistest. Schriftenreihe: Zukunft und Forschung (eds. R. Popp, A. Zweck), Bd. 3, Berlin, Heidelberg: Springer, pp. 385-407. https://doi.org/10.1007/978-3-531-19837-8_16

Knight F.H. (1921) Cost of production and price over long and short periods. Journal of Political Economy, 29(4), 304-335. https://doi. org/10.1086/253349

Kononiuk A., Gudanowska A., Magruk A., Sacio-Szymańska A., Fantoni G., Trivelli L., Ollenburg S. (2017) Becoming FutureOriented Entrepreneurs in Universities and Companies (WP1 report), Brussels: European Commission. http://futureoriented.eu/wpcontent/uploads/wplf.pdf, accessed 18.01.2021.

Kononiuk A., Pająk A., Gudanowska A., Magruk A., Rollnik-Sadowska E., Sacio-Szymańska A. (2020) Foresight for Career Development. Foresight and STI Governance 14(2), 88-104.

Kreibich R., Oertel B., Wölk M. (2011) Futures Studies and Future-Oriented Technology Analysis Principles, Methodology and Research (HIIG Discussion Paper Series Discussion Paper 2012-05). Paper presented for the 1st Berlin Symposium on Internet and Society, October 25-27. DOI:10.2139/ssrn.2094215 
Lefebvre C., Glanville J., Wieland L.S., Coles B., Weightman A.L. (2013) Methodological developments in searching for studies for systematic reviews: Past, present and future? Systematic Reviews, 2(1),78. DOI: 10.1186/2046-4053-2-78.

Lewrick M., Maktoba O., Raeside R., Sailer K. (2010) Education for Entrepreneurship and Innovation: Management Capabilities for Sustainable Growth and Success. World Journal of Entrepreneurship, Management and Sustainable Development, 6(1-2), 1-18. http:// dx.doi.org/10.1108/20425961201000001

Martin R.L. (2019) The high price of efficiency. Harvard Business Review, January-February, 42-55. https://hbr.org/2019/01/the-high-priceof-efficiency, accessed 28.06.2021.

Merrill M.D. (2002) First principles of instruction. Educational Technology Research and Development, 50, 43-59. https://doi.org/10.1007/ BF02505024

Miller R. (2015) Learning, the Future, and Complexity. An Essay on the Emergence of Futures Literacy. European Journal of Education, 50(4), 513-523. https://doi.org/10.1111/ejed.12157

Miller R. (2018) Transforming the future: Anticipation in the 21st century, New York: Routledge. https://doi.org/10.4324/9781351048002

Morris M.H., Webb J.W., Fu J., Singhal S. (2013) A competency-based perspective on entrepreneurship education: Conceptual and empirical insights. Journal of Small Business Management, 51(3), 352-369. https://doi.org/10.1111/jsbm.12023

Nanus B. (1977) Management training in futures concepts. Futures, 9(3), 194-204. https://doi.org/10.1016/0016-3287(77)90033-7

Postma A., Yeoman S. (2021) A systems perspective as a tool to understand disruption in travel and tourism. Journal of Tourism Futures, $7(1), 67-77$.

Ratcliffe J., Ratcliffe L. (2015) Anticipatory leadership and strategic foresight: Five 'linked literacies'. Journal of Futures Studies, 20, pp. 1-18.

Rieckmann M. (2011) Future-oriented higher education: Which key competencies should be fostered through university teaching and learning? Futures, 44, 127-135. https://doi.org/10.1016/j.futures.2011.09.005

Rohrbeck R. (2011) Corporate foresight: Towards a maturity model for the future orientation of a firm, Heidelberg: Physica-Verlag. https:// doi.org/10.1007/978-3-7908-2626-5

Roos J. (2014) The Renaissance We Need In Business Education. Harvard Business Review, July. https://hbr.org/2014/07/the-renaissance-weneed-in-business-education/, accessed 24.06.2020.

Rudzinski C.V., Uerz G. (2014) Volkswagen: Open Foresight at the Front End of Research Innovation. In: Management of the Fuzzy Front End of Innovation (eds. O. Gassmann, F. Schweitzer), Heildelberg, Dordrecht, London, New York: Springer, pp. 295-299.

Sajwani Z.S., Hazzam J., Lahrech A., Alnuaimi M. (2021) A strategy tripod perspective on merger effectiveness in the higher education industry: The mediating role of future foresight. International Journal of Educational Management, 35(5), 925-942.

Schumpeter J.A. (1934) The Theory of Economic Development, Cambridge, MA: Harvard University Press.

Snelbecker G. (1983) Learning theory, instructional theory, and psychoeducational design, New York: McGraw-Hill.

Song A., Hormuth W. (2013) Die BASF Future Business GmbH. Vom Trendscouting zum Aufbau neuer Geschäftsfelder. In: Zukunftsforschung im Praxistest. Schriftenreihe: Zukunft und Forschung (eds. R. Popp, A. Zweck), Bd. 3, Berlin, Heidelberg: Springer, pp. 181-194.

Stordy P. (2015) Taxonomy of literacies. Journal of Documentation, 71(3), 456-476. https://doi.org/10.1108/JD-10-2013-0128

Suleiman A., Abahre J. (2020) Essential competencies for engineers from the perspective of fresh graduates. Engineering Management in Production and Services, 12(1), 70-79. DOI: 10.2478/emj-2020-0006.

Thomassen M.L., Middleton K.W., Ramsgaard M.B., Neergaard H., Warren L. (2019) Conceptualizing context in entrepreneurship education: A literature review. International Journal of Entrepreneurial Behavior \& Research, 26(5), 863-886. https://doi.org/10.1108/ IJEBR-04-2018-0258

Valerio A., Parton B., Robb A. (2014) Entrepreneurship Education and Training Programs around the World: Dimensions for Success, Washington, DC: World Bank. DOI: 10.1596/978-1-4648-0202.

van Atta R.H., Lippitz M.J., Bovey R.L., Dubin R.D., Blazek S.L. (2011) Commercial Industry Research \& Development Management Best Practices, Alexandria, VA: Institute for Defense Analysis.

van der Heijden K. (2000) Scenarios: The Art of Strategic Conversation (2nd ed.), Hoboken, NJ: Wiley.

van der Laan L. (2010) Foresight competence and the strategic thinking of strategy-level leaders. Toowoomba: University of Southern Queensland.

van der Laan L., Erwee R. (2012) Foresight styles assessment: A valid and reliable measure of dimensions of foresight competence? Foresight, 14(5), 374-386. https://doi.org/10.1108/14636681211269860

Volpentesta A.P., Felicetti A.M. (2011) Competence Mapping through Analysing Research Papers of a Scientific Community. In: Technological Innovation for Sustainability. DoCEIS 2011. IFIP Advances in Information and Communication Technology (ed. L.M. Camarinha-Matos), vol. 349. Springer, Berlin, Heidelberg. https://doi.org/10. 1007/978-3-642-19170-1_4

Walras L. (1954) Elements of Pure Economics, London: Allen \& Unwin.

Weiner E., Brown A. (2008) FutureThink: How to Think Clearly in a Time of Change, New York: FT Press.

Wippel N. (2014) Multinational strategic foresight of environmental trends in the automobile industry using internal resources, Bremen: University of Bremen.

Xu Y., Yeh C.-H. (2012) An integrated approach to evaluation and planning of best practices. Omega, 40(1), 65-78. 